Flier, A. Ia. (2011) Kul'turologiia v obrazovanii i ee vozmozhnosti po sotsializatsii i inkul'turatsii lichnosti. In: Na puti k kul' turnoi paradigme sovremennogo obrazovaniia. St. Petersburg, SPbGUP. (Uchenye zapiski. Vol. 1). Pp. 185-186. (In Russ.).

Flier, A. Ia. (2017) Parametry svoeobraziia natsional'nogo kul'turnogo naslediia. Voprosy kul'turologii, no. 10, pp. 36-44. (In Russ.).

Flier, A. Ia. (2018) Religioznye i khudozhestvennye obrazy kak voploshchenie etalonnykh kul'turnykh norm. Vestnik kul'tury i iskusstv, no. 1 (53), pp. 35-42. (In Russ.).

Frankfort, G., Frankfort, G. A., Uilson, Dzh. and Iakobsen, T. (1984) V preddverii filosofii. Dukhovnye iskaniia drevnego cheloveka. Moscow, Nauka. 236 p. (In Russ.).

Submission date: 12.02.2018.

Флиер Андрей Яковлевич — доктор философских наук, профессор, главный научный сотрудник Российского научно-исследовательского института культурного и природного наследия им. А. С. Аихачева. Адрес: 129366, Россия, г. Москва, ул. Космонавтов, д. 2. Тел.: +7 (495) 686-13-19. Эл. axpec: andrey.flier@yandex.ru

Flier Andrey Yakovlevich, Doctor of Philosophy, Professor, Chief Research Fellow, Russian Scientific Research Institute for Cultural and Natural Heritage named after D. Likhachev. Postal address: 2, Kosmonavtov St., Moscow, Russian Federation, 129366. Tel.: +7 (495) 686-13-19. E-mail: andrey. flier@yandex.ru

DOI: $10.17805 /$ zpu.2018.2.13

\title{
Детско-юношеские общественные движения и отечественная детская периодика как факторы ценностного самоопределения личности
}

\author{
Ю. А. ГОЛОВИН, О. Е. КОХАНАЯ \\ МОСКОВСКИЙ ГУМАНИТАРНЫЙ УНИВЕРСИТЕТ
}

Авторы рассматривают историю развития детско-юношеского общественного движения в России во взаимосвязи с развитием отечественной детской периодики, которая выступала фактором воспитания, формирования ценностей участников движений.

Прообразом первых детско-юношеских общественных организаций стало скаутское движение, появившееся в Великобритании в начале XX в. Идеи Р. Баден-Пауэлла нашли последователей и в России. Главной отличительной чертой российского скаутинга явилась военно-патриотическая направленность. Анализируя ситуацию быстрого распространения скаутского движения в России, авторы приходят к выводу, что это стало возможным благодаря созданию эффективной модели функционирования скаутских СМИ. На основании исследования дореволюционных отечественных средств массовой информации для детей и юношества авторы доказывают, что пионерские СМИ, созданные в первые годы советской власти, были организованы и функционировали по той же модели, только с другой идеологической наполненностью. При этом доминирующим вектором и в новой политической системе координат осталось патриотическое воспитание молодого поколения.

Следующим этапом стала деятельность СМИ «допионерского периода», система функционирования пионерской организации в жизни детей в СССР (1920-1980-е годы.). Этап отличался совместной деятельностью с комсомольскими организациями в борьбе с бес- 
призорничеством, ликвидацией неграмотности в 1920-1930-е годы, в подготовке юношества к службе в Советской армии и т. д. Новые формы организации детей и молодежи (добровольчество и волонтерство) также имеют свои СМИ.

Очевидна преемственность традиций и принципов патриотического, нравственного воспитания, уважения к личности ребенка в досоветский и советский период развития нашей страны. Воздействие системы отечественных СМИ для детей в СССР беспрецедентно по масштабу целей и задач, по массовому охвату и вовлечению молодого поколения в добровольные общественные движения.

Ключевые слова: патриотическое воспитание; ценностное самоопределение; детскоюношеские общественные организации; скаутинг; пионерская организация; средства массовой информации; периодическая печать; добровольчество; волонтерство; история России; история СССР

\section{BВЕАЕНИЕ}

П ервая четверть ХХ в. открывает качественно новую страницу в отечественной периодике о детях и для детей, связанную с социально-педагогическим феноменом, именуемым детское общественное движение. Аолгий спор критиков, педагогов, литературоведов XIX в. о том, нужна ли детям периодика, а в ней - отражение проблем и событий современности, разрешили сами юные граждане, разрешило время. Нужно слово, которое бы несло полезные знания, обучало, подсказывало, ободряло. Нужны средства информации - газеты, журналы, брошюры, книги, а в перспективе и әлектронные их версии, которые бы говорили на том же языке, что и сами участники детского движения. Нужно быть уверенным, что есть куда обратиться с вопросом, выразить свое личное или коллективное мнение по поводу волнующих событий в своем детском сообществе, в семье, в стране; откуда черпать информацию о ровесниках участниках детского движения, их делах и жизни. Нужны были свои, детские СМИ.

Объективная потребность детского общественного движения в информационном сопровождении обусловила создание целого информационного потока книг, брошюр, журналов, газет, поначалу связанных с деятельностью детских скаутских объединений, который пророс на русской почве в первом десятилетии ХХ в. (Головин, Зарахович, Коханая, 2011: 42-43), а затем и новой молодой ветви советской журналистики, которая со временем стала мощным источником информирования, воспитания и организации коллективной общественно полезной деятельности на благо Родины ее самых юных граждан: пионерии и комсомола.

Закончился юбилейный 2017 г. - год столетия русских революций. Аумается, пришло время «собирать камни», восстанавливать, по возможности беспристрастно, историю нашей великой Родины, анализировать этапы большого пути, национальный менталитет, культурную самоидентичность.

\section{СКАУТИНГ И СОВЕТСКАЯ ПЕЧАТЬ АОПИОНЕРСКОГО ПЕРИОАА}

В литературе скаутинг широко представлен прежде всего в методических руководствах и указаниях, созданных основателем и последователями воспитательной системы (Р. Баден-Пауэлл, Г. А. Захарченко, О. И. Пантюхов, В. А. Попов, В. С. Преображенский и др.). В научных работах современных российских исследователей осуществляется осмысление истории и практики скаутинга в историческом пространстве России и мире (Н. Ф. Басов, А. А. Бондарь, И. А. Булатов, В. И. Аовбыщенко, В. А. Кудинов, Ю. В. Кудряшов, Т. П. Кузнецова, В. А. Кучин, Е. А. Подтынная, О. В. Попова, Е. П. Пупкова, А. П. Савченко, Е. Ю. Сейку, М. В. Фуре, В. Е. Черных, А. В. Ярмольчук и др.). Организованное детско-юношеское движение, получившее название «скау- 
тинг», появилось в Великобритании в начале XX в. и первоначально имело явно военизированную окраску. Аидеры скаутов основателем движения считают британского военачальника, писателя, художника лорда Роберта Баден-Пауэлла (1857-1941), сформулировавшего основные идеи скаутинга (Баден-Пауэлл, 2001). С самого начала в своей практической деятельности скауты использовали игровые методы. В 1907 г. Р. Баден-Пауэлл вывел подростков в палаточный лагерь: этот факт принято считать началом скаутского движения. В Великобритании по всей стране стали возникать скаутские группы. Возможно, эта система и осталась бы только среди военных и той части молодежи, которая свое будущее связывала с военной службой, если бы к ее совершенствованию не приложили руку известный английский и канадский писатели Редьярд Киплинг (1865-1936) и ученый-эколог, натуралист, писатель и художник Эрнст Сетон-Томпсон (1860-1946). Еще в 1902 г. Э. Сетон-Томпсон создал детское движение «индейцев - знатоков леса» (Woodcraft indiens), в основе которого лежала мысль о том, что каждый человек должен жить в единстве с природой, научиться хорошо понимать ее, уметь выживать в природных условиях. Это движение распространялось медленно. Когда в США в 1910 г. появились скауты, Сетон-Томпсон горячо поддержал это начинание и даже позднее стал Старшим скаутов в первой организация бойскаутов в Америке.

Новаторство скаутинга было в том, что в нем соединили детей и взрослых в одной организации в процессе совместной деятельности, общей длительной игры в разведчиков, в стремлении быть полезными другим людям, природе и миру в целом. У БаденПауэлла отношения между взрослыми и детьми строились как равноправные, где взрослый и ребенок играли каждый свою роль, ребенок добровольно соглашался с позицией и ролью взрослого как старшего товарища, более знающего, более умелого. Взрослый вел за собой младшего. Так в скаутской организации отчасти была решена проблема антагонизма между взрослыми и детьми. Баден-Пауэлл понял стремление детей и подростков к неформальному общению, он уловил их желание объединиться между собой для реализации своих интересов и потребностей. Универсальность системы скаутинг заключается в ее саморазвитии. Она соединяла в одну организацию подростков и взрослых независимо от религиозных конфессий - не только католической Европы, но и православных народов, мусульманского мира, различных рас и этносов (Кучин, 2008). Фактически скаутинг заложил основы педагогики нового типа, которая впоследствии в СССР получила название неформальной педагогики (Кордонский, Кожаринов, 2008) в противовес формальному (обязательному) школьному образованию.

В России первые скаутские отряды появились в 1907 г., но цели, задачи, принципы и методики деятельности детской организации, созданной Баден-Пауэллом, трансформировались в нашей стране с определенной корректировкой на национальный менталитет и творческий поиск русских энтузиастов скаутского движения (Иннокентий Жуков, Олег Пантюхов, Григорий Захарченко) (Попов, Преображенский, 1917). Первых организаторов юных разведчиков в России поддержал император Николай II. Он и командировал их в 1910 г. ознакомиться подробнее с опытом работы в Англию, Голландию, Аанию, Швецию. Получив информацию о деятельности зарубежных скаутов, император еще более убедился в ценности зарубежного опыта воспитания молодежи.

В декабре 1915 г. состоялся Первый Всероссийский съезд инструкторов и лиц, интересующихся скаутизмом. К нему было привлечено внимание общественных органи- 
заций и властных структур. Сам император Николай II пожелал успеха развитию скаутизма в России. На съезде местные организации соединились во Всероссийский союз скаутов, секретарем которого стал скульптор и педагог И. Н. Жуков.

В соответствии с уставом, принятым на съезде, в отряды принимались юноши и девушки с 12 до 18 лет. Скаут-мастера (взрослые) входили в организации на равных с подростками, из этого следует, что возраст не был ограничен. Аетей рабочих и крестьян можно было насчитать единицы, в отряды они почти не вступали из-за отсутствия денег на покупку формы. Помимо прямого участия в боевых действиях во время Первой мировой и Гражданской войны, за что некоторые скауты были отмечены боевыми наградами, члены организации разгружали санитарные поезда с ранеными, ухаживали за ними в госпиталях, оказывали помощь семьям пострадавших, проводили разведку и др.

Интересно отметить, что в 1915 г. поэтом Николаем Адуевым был написан гимн скаутов «Будь готов!», положенный на музыку редактором журнала «Вокруг света» Владимиром Поповым, являвшимся начальником Московской дружины скаутов. В. Попову также принадлежат слова и музыка популярной скаутской песни «Картошка», известной в СССР как пионерская песня (Ермолин, 2004).

Скаутизм как одно из самых влиятельных в дореволюционной России детскоюношеских общественных объединений и новое явление российской жизни открывает и принципиально новую страницу в истории отечественной периодики для детей, т. е. печати, призванной обслуживать не отдельных читателей: мальчиков и девочек, а целую организацию, в которой они состоят. Скаутские СМИ активно развивались: от единичных с 1907 г. до десятка книг и справочников в 1919-1922 гг. К этому времени уже десятки скаутских журналов издавались от западных до восточных границ: «Петроградский скаут», «Русский скаут» (Петроград), «Аесятка» (Петроград), «Царскосельский скаут», «Будь готов!» (Москва), «Скаут русского Севера» (ВологАа), «Заря скаутизма» (Иркутск), «Владивостокский скаут», «Северный скаут» (Архангельск), «Вестник скаута» (Архангельск), «Скаут Западной Сибири» (Челябинск),

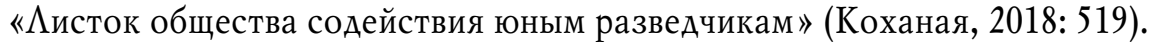

Знаменательно, что параллельно специальные скаутские издания адресуются взрослым участникам движения - скаут-мастерам. Растет количество сборников и пособий по вопросам скаутизма, авторами которых были сами скаут-мастера О. И. Пантюхов, И. Н. Жуков, В. А. Попов, В. С. Преображенский, А. К. Анохин и другие российские энтузиасты скаутизма. Например, книга Р. Баден-Пауэлла «Юный разведчик» в 1910 г. была переведена и авторски переработана Г. Захарченко, сумевшим осмыслить и предложить русский вариант применения системы скаутинга с позиций военно-спортивного воспитания мальчиков в духе былинной героики русского прошлого (Головин, Зарахович, Коханая, 2011: 43-44).

После Октябрьской революции 1917 г. информационное сопровождение скаутского движения, как и сам скаутинг, уже имело оппонента - советскую печать допионерского периода. Следует заметить, что печать, обслуживавшая скаутское движение в России, во многом стимулировала рождение и становление печати будущей Всероссийской пионерской организации, официальным днем рождения которой объявлена всем известная дата: 19 мая 1922 г.

Надо сказать, что именно в период развития скаутинга на русской почве сложилась модель информационного сопровождения детского движения как таковая, которая впоследствии фактически была использована и воплощена в жизнь совет- 
ской властью. Выделим основные принципы информационной модели скаутских организаций:

- многоступенчатость и многоадресность средств массовой информации в соответствии с категориями участников движения: от самой нижней, первичной ступени (дети-скауты) до самой верхней (взрослые лидеры);

- видовое разнообразие СМИ - от информационного листка до научных справочников, теоретических исследований;

- гендерный подход - издания для бойскаутов и герлскаутов;

- сочетание скаутинга как системы с конкретно-историческими, национальными, территориальными, общественно-политическими данностями нашей страны;

- привлечение в авторский круг как профессионалов, ученых, педагогов, так и практиков, опытных и новичков;

- открытость, дискуссионность, популяризаторство в сочетании с научным подХОдОМ.

В общем виде эта модель выглядела так:

- периодические издания, адресованные детям: листки, журналы, газеты;

- периодика для взрослых организаторов движения;

- аналитические статьи и выступления в педагогических журналах;

- справочники, монографии, брошюры (включены в модель, несмотря на то что не являются периодическими изданиями, но логически дополняют информационное поле скаутского движения).

Параллельно со скаутскими информационными потоками появляются и отдельные периодические издания, сопровождающие и освещающие деятельность иных детских общественных объединений. Это журнал «Юные товарищи» (апрель, 1922), «Юный пролетарий» - орган Петроградского губкома РКСМ (1919), «Костер» - орган Орловской трудовой дружины (1922), «Творцы будущего» (1920, Оренбуржье), московские самодеятельные издания: журнал «Шум», альманахи детского творчества. В первые годы советской власти также выходят журналы «В мастерской природы» (1919-1929) и «Воробей» (1923-1925). Начинает издаваться детская периодика в разных городах страны: в Ташкенте - «Юный туркестанец» (1919-1920), в Киеве - «Радуга» и «Ковер-самолет» (1918-1919), в Туле - «Красная звездочка» (1922-1924). Аетские журналы выходят в Тбилиси, Ереване, Чите, Симбирске, Нижнем Новгороде, Пензе, Хабаровске, Ростове-на-Аону, Новосибирске.

Конец XIX - начало XX в. ознаменованы для детской журналистики появлением в ней писателя Максима Горького - вначале как автора журнала «Всходы», а затем и как одного из зачинателей детской журналистики. М. Горький стал основателем первого советского «допионерского» журнала для детей «Северное сияние» (1919-1920). «В предлагаемом журнале мы... будем стремиться воспитать в детях дух активности, интерес и уважение к силе разума, к поискам науки, к великой задаче искусства сделать человека сильным и красивым» - так определял цель журнала М. Горький (Северное сияние ..., 1919: 3). Тематика журнала созвучна своему времени: труд, мужество, революционная борьба, устремленность в будущее. Можно выделить некий «горьковский» подход к содержанию и тональности детских изданий. Писатель видел их революционными по духу, демократическими по содержанию и романтическими по тональности и по форме. Начиная с 1920-х годов в истории журналистики для детей наступает новый этап, который можно назвать «Аетская организация и СМИ» (Головин, Зарахович, Коханая, 2011: 41-42). 
Новая детская периодика противостояла влиянию на детей журналов иной идеологической направленности, таких как «Божья нива», «Светлячок», и изданий скаутских организаций («Заря скаутизма»).

В связи с этим следует отметить, что скаутизм в первые годы советской власти воспринимался и осмысливался в обществе как буржуазное общественное детское движение. В то же время видные общественные и политические деятели, выступившие за создание новой детской коммунистической организации, - Н. К. Крупская, В. А. Зорин и другие - ратовали за то, чтобы взять от скаутизма все лучшее и использовать это во благо воспитания в советском духе.

Таким образом, два разных пути развития детского общественного движения нашли свое отражение и в издаваемых в ту пору журналах. Ао создания пионерской организации это было естественно и правомерно, но со временем, когда пионерская организация завоевала популярность и стала основной в стране, а скаутские отряды распались, вместе с ними прекратили свое существование и скаутские журналы.

$\mathrm{B}$ начале $\mathrm{XX}$ столетия завершился этап развития детской журналистики, который правомерно было бы назвать «допионерским».

\section{ПИОНЕРСКИЕ И КОМСОМОАЬСКИЕ ОБЩЕСТВЕННЫЕ АВИЖЕНИЯ И ЕАИНАЯ СИСТЕМА АЕТСКО-ЮНОШЕСКИХ СМИ}

Можно предположить, что если бы в Советском Союзе были созданы условия для свободного развития детского движения, вкдючающего в себя наравне со скаутским множество иных ветвей, то и соответствующие им СМИ со временем представляли бы огромное информационное пространство, на котором бы в свободном полете пробовали крылья, экспериментировали, набирали высоту различные печатные издания, затем радио- и телепрограммы и т. А. Но у истории нет сослагательного наклонения. И произошло то, что произошло. Единственная на тот момент и первая в мире страна Великой Октябрьской социалистической революции, заботившаяся о наследовании юным поколением революционного дела, повернула «колесо рулевое» на путь единой детской пионерской организации, а в области информации - на путь создания комплекса СМИ, который бы обслуживал, с одной стороны, эту самую организацию, а с другой был бы звеном в единой системе средств массовой информации комсомола и партии. Но при этом следует признать, что исторический опыт скаутских СМИ не был проигнорирован: пригодился сам подход к формированию информационного блока (модели). И если вспомнить последние десятилетия советского периода нашей страны (1970-1980-е годы), то мы увидим, что единая система пионерских СМИ успешно функционировала по модели информационного сопровождения скаутской организации (см. выше):

- периодические издания, адресованные детям: листки, журналы, газеты. Перечислим только некоторые из СМИ союзного уровня - журналы «Мурзилка», «Веселые картинки», «Пионер», «Костер», «Юный натуралист», «Юный техник»; газеты «Пионерская правда», «Комсомольская правда»; радиопередачи «Пионерская зорька», «Радионяня», «Ровесники»; тележурнал «Ералаш», телепередачи «Будильник», «АБВГАейка» и др.;

- периодика для взрослых организаторов движения: журналы «Вожатый», «Затейник», «Клуб и художественная самодеятельность», «Комсомольская жизнь» и др.;

- аналитические статьи и выступления в педагогических газетах и журналах: «Учительская газета», «Советская педагогика», «Педагогический мир», «Педагогический журнал» и др. 
Такая многоступенчатая, многоадресная модель сложилась отнюдь не сразу. Аля этого потребовалось не менее трех десятилетий: с 1922 г. до 1950-х годов, исключая трудное время войны (1941-1945), когда было не до новых изданий. Но зато изначально определилось сущностное, функциональное предназначение информационного сопровождения пионерской и комсомольской организации. Очевидно, социокультурные функции детских СМИ соответствовали духу времени. Ааже в этой жесточайшей ситуации разрушения в нашем Отечестве «мира Божьего» и построения, по словам советского детского писателя Аркадия Гайдара, «солнечного царства социализма» присутствовала, как ни странно, преемственность функционирования социокультурных институтов.

Пионерские СМИ формировались как самая молодая ветвь всей системы партийно-комсомольской печати в соответствии с целями и задачами детской организации как звена в общественно-политической системе Советского государства в неразрывном триединстве: партия, комсомол и пионерия. И поэтому вполне логично и закономерно, что ряд сущностных задач (функций) партийных СМИ трансформировались в пионерские.

Первая функция, идеологическая, аналогична партийной - соединить энтузиазм и инициативу детей рабочих и крестьян (а именно они поначалу становились пионерами) с идеями революции, строительства первого в мире социалистического государства. Процесс постоянного взаимодействия идейных основ строительства социализма, доступно преподносимых детям в форме лозунгов, призывов, обращений, с практической деятельностью массовой детской организации (трудовой, спортивной, познавательной, военно-патриотической, художественной) давал в результате коллективное знание, представление о ценностях, мировоззрение.

Героические примеры из жизни революционеров, участников Гражданской войны, отцов и дедов, молодых современников, ровесников пионеров, их бескорыстное служение народу, Родине, образы реальных героев, удостоенных высших правительственных наград, и героев литературных (Тимур из повести А. Гайдара «Тимур и его команда») служили идеалом, нравственным ориентиром в коллективном воспитании и личном самовоспитании. Так осуществлялась функция педагогическая.

И, наконец, ленинская формула, определяющая газету как коллективного организатора, стала основой массовых инициатив и кампаний на всем историческом пути пионерской печати, основой для разработки самых различных проектов (как принято это называть сегодня) общественно полезной, патриотической, гражданской направленности. Проектов, участие в которых принимали миллионы пионеров страны, в чем и проявилась функция организаторская.

Знаменательно, что первый печатный центральный орган был адресован взрослым, которым предстояло осуществить небывалый в истории социально-педагогический эксперимент - создание массовой детской коммунистической организации и руководство ею. Так, в июне 1924 г. стартовал легендарный журнал «Вожатый», которому сразу же пришлось проявить бойцовский характер, отстаивая на своих страницах новые идеи и принципы детской организации, отличные от скаутской (там же: 46-47).

Центральными органами Всесоюзной пионерской организации становятся литературные журналы: для подростков - «Пионер» и «Костер», для детей, дошкольников и младших школьников - «Мурзилка»; методический журнал «Вожатый»; профильные (или специализированные) журналы по интересам «Юный художник», «Юный 
техник», «Юный натуралист», «Моделист-конструктор» (Головин, 2010: 192-194). Каждая союзная республика имела свою печать для детей наряду с центральными периодическими изданиями.

Начиная с 1920-х годов складывалась и постоянно совершенствовалась целостная система пионерской печати, в которой главным изданием выступает массовая газета «Пионерская правда» (первый номер газеты вышел 6 марта 1925 г.). Ей принадлежит роль первопроходца в освещении и утверждении нового понятия патриотизма как патриотизма советского, социалистического в единстве с интернационализмом. Суть в том, что газета, информируя детей о жизни и событиях многонационального Советского Союза, включает их в многообразную деятельность на благо своей страны. Рождаются новые интерактивные формы вовлечения читателей в заботы страны и народа: кампании, движения, конкурсы, всесоюзные экспедиции, познавательные турниры, трудовые операции, военно-спортивные игры, спортивные всесоюзные соревнования, слеты и другие массовые движения ${ }^{1}$. Газета становится своего рода зеркалом истории строительства нового мира и участия детей в этом процессе. Вспомним лишь некоторые этапы большого созидательного пути.

В 1927 г., когда страну буквально заполнили дети, получившие название «беспризорники», на страницах газеты появляется лозунг: «Беспризорным жить невмочь, пионер им должен помочь!». Газета призывала привести ребят в детские дома, подсказывала пути, как это сделать. На страницах газеты публиковались фотографии этих ребят, газета не боялась представить юным читателям мир современного детства со всеми его изъянами и бедами. В одной из корреспонденций юнкоры докладывали, как им удалось пристроить беспризорников на работу в кооператив.

2 июля 1929 г. «Пионерская правда» привлекла ребят к еще одной социальной проблеме тех лет: в стране 89 млн неграмотных. И снова газета находит точные слова, чтобы мобилизовать ребят к ликвидации неграмотности: «Каждый из нас - солдат ликбезовского похода - грамотный, обучи неграмотного!». И ребята сами искали пути и формы, чтобы помочь взрослым освоить азы и навыки письма и чтения. К 1930 г., по данным газеты, пионеры обучили грамоте свыше 1 млн неграмотных.

Наряду с привлечением детей к посильному участию в делах взрослых газета обращалась к читателям с понятными и близкими их возрасту проектами. Один из самых ярких примеров - обращение М. Горького 13 июля 1933 г.: «Что вы читаете? Какие книги нравятся вам? Какие книжки вы желали бы прочитать?.. Что именно вы хотели бы знать? Какие вопросы интересуют вас?.. Письма присылайте в редакцию "Пионерской правды”, а кто хочет, пусть посылает мне» (Горький, 1953). Письмо М. Горького вызвало горячий интерес ребят и помогло созданию первого специального издательства детской литературы - «Аетская литература» (первоначально "Аетгиз»).

24 января 1937 г. на страницах «Пионерской правды» (или как ласково называли издание читатели - «Пионерки») публикуется письмо пионеров отряда имени Серго Орджоникидзе: «Пусть к двадцатилетию советской власти на груди у каждого пионера и пионерки засияют три оборонных значка. Этим мы докажем, что, любя свою Родину, каждый из нас готовится храбро и беззаветно защищать ее» (Пионерская правда, 1937: 1; Пионерия, 2018: Электронный ресурс). И уже в 1938 г. газета обращается к пионерам всех республик: «Учись оборонять свою Родину!» и публикует снимок ребят, у каждого из которых на груди оборонные значки ГТО: «Будь готов к труду и обороне», «Будь готов к санитарной обороне», «Будь готов к противовоздушной обороне», «Ворошиловский стрелок» и «Ворошиловский всадник». Призыв оказался 
своевременным: вскоре дети помогали взрослым, как когда-то скауты, только уже в Великой Отечественной войне.

По призыву газеты в годы войны ребята организовывали сбор средств на строительство военной техники. В боях участвовала танковая колонна «Московский пионер», самолет «Пионерская правда», танк «За Таню». На страницах военной «Пионерской правды» остался след малых и больших дел юных патриотов: на заводах и колхозных полях, в школе юнг в Соловках и на оккупированной территории, в партизанских отрядах.

Одна из самых ярких страниц «Пионерки»- публикация в 1940 г. повести Аркадия Гайдара «Тимур и его команда». Тимуровское движение, рожденное до войны, получило огромный размах в 1941-1945 гг., когда почти из каждой семьи ушли на фронт отцы, деды, братья и сестры. Фактически до конца 1980-х годов, до начала перестройки, по всей стране пионеры осуществляли миссию помощи нуждающимся в человеческом внимании пожилым людям, ветеранам: каждый пионерский школьный класс участвовал в тимуровском движении.

Итак, в одних случаях инициатива подобных общественно полезных начинаний принадлежала самой газете, в других - редакция поддерживала интересные инициативы, рожденные самими ребятами, через газету делая их достоянием всех пионеров страны. Военно-патриотическая деятельность газеты в годы войны была направлена на организацию коллективных общественных дел пионеров и школьников, поддержку различных патриотических инициатив отдельных ребят, отрядов, звеньев, дружин.

На послевоенном этапе, в мирную пору, для пробуждения и формирования у детей чувства Родины нужно искать иные пути и средства, иное слово. Но при всех сложностях редакции было ясно одно: действовать надо через привлечение детей к насущным заботам народа. Необходимо было восстанавливать изуродованную войной родную землю. И появляется тема созидательного труда! 19 апреля 1946 г. газета обратилась к своим читателям: «Ребята! Если каждый из вас посадит один-два саженца, через несколько лет в нашей стране вырастут миллионы новых фруктовых деревьев. За дело, Арузья!» (Пионерская правда, 1946: 1). Начинание «Пионерки» поддержал ЦК В $\Lambda$ КСМ. 1947 г. стал началом ежегодного Всесоюзного конкурса на лучшего юного садовода. Более 5 млн школьников приняли в нем участие. По призыву газеты: «Соберем для нашей страны тысячи тонн семян клевера, тимофеевки и люцерны!» ребята собрали и сдали колхозам, совхозам сотни килограммов семян дикорастущих трав.

Подхватив инициативу одного из московских пионерских отрядов, носящих имя знаменитого русского путешественника Н. Н. Миклухо-Маклая, газета в 1947 г. обратилась к юным читателям: «Мы уверены, что его примеру последуют тысячи пионерских отрядов всех республик Советского Союза» (Головин, Зарахович, Коханая, 2011: 65). С этого началась Всесоюзная экспедиция пионеров и школьников «Моя Родина - СССР». Более 3 млн пионеров и школьников участвовали уже в 1947 г. в походах. Ребята собирались на районные, городские и - при организаторской поддержке редакции и ЦК ВАКСМ - Всесоюзные слеты юных путешественников. Газета умело направляла участников экспедиции на конкретные участки деятельности: охрану мальков ценных промысловых рыб, разведку полезных ископаемых, работу на колхозных полях, помощь в сборке автомашин. Газета публиковала сообщения из экспедиций. Из 10 тыс. заявок юных геологов на разработку приисков обнаруженных ими золота, аметистов, топазов и пр. - 1500 заявок заинтересовали специалистов. 
В 1950-е годы «Пионерка» поддержала такие начинания, как «Пионерские рельсы» на трассу «Абакан - Тайшет» (авторы проекта - пионерский актив средних школ московского железнодорожного узла); «Пионерский металл» для нефтепровода «Аружба» - эта инициатива принадлежала пионерам дружины им. Шандора Петефи из Венгрии. Таким образом, родилось общее, не только патриотическое, но и интернациональное дело, что сблизило детей Польши, ГАР, Венгрии, Чехословакии, CСCP.

Одним из главных патриотических начинаний газеты в 1970-е годы стала знаменитая «Зарница» - военно-спортивная, широкомасштабная всесоюзная игра. Она шагнула со страниц «Пионерки» и быстро завоевала популярность. При редакции был создан главный штаб игры. В программе «Зарницы» были операции на местности, ориентирование, овладение юнармейскими специальностями, состязания в различных видах спорта, смотры строя и песни. Игры начинались с масштабов двора, дружины, района и далее доходили до всесоюзных финальных соревнований, где юнармейцы демонстрировали свои умения и навыки, ловкость и собранность, а в целом готовность, когда придет время, служить Родине в рядах ее защитников. Как тут не вспомнить скаутов начала XX в.!

Вот как оценивал дважды Герой Советского Союза, маршал Советского Союза И. Х. Баграмян деятельность газеты в этом направлении: «Все свои 50 лет "Пионерская правда" дружит с нашей славной армией; солдаты, офицеры, генералы, маршалы разговаривают с вами об очень важном - о служении Родине, ее защите... А как этому научиться? Ну, конечно, в военной игре, в “Зарнице”...» (там же: 68).

1970-е годы вошли в историю газеты и как годы крупных трудовых кампаний, объединивших читателей вокруг «Пионерстроя», мобилизуя пионеров и школьников на всесоюзные общественно полезные дела. Это и сбор металлолома для строительства БАМа - Байкало-Амурской магистрали, и Всесоюзная операция по сбору макулатуры «Миллион - Родине!»

Опыт газеты «Пионерская правда» показывает, что печатный орган, создаваемый объединенными усилиями взрослых и детей, несет в себе огромный воспитательный потенциал. «Пионерская правда» представляет собой образец журналистики, адресованной детям, учитывающей психологические особенности их возраста, вкусы, интересы, потребности. Редакцией газеты были задуманы и апробированы новаторские формы и методы активизации детской аудитории и обратной связи с ней: проведение целевых краткосрочных и долгосрочных акций. Правомерно считать уникальным явлением в истории мировой печати создание в СССР детской массовой организации и ее СМИ, рассчитанных на многомиллионную аудиторию читателей.

Системный подход к печати соответствовал системе строительства общественных организаций: партия - комсомол - пионерская организация. Печать: партийная комсомольская - пионерская. А внутри пионерского блока своя подсистема: издания, объединяющие всех членов детской коммунистической организации - «Пионерская правда», журнал «Пионер»; издания для разных возрастных групп и приверженцев различных увлечений (искусство, техника, природа и т. А.); специальное издание для взрослых, непосредственно связанных с пионерией, тех, кто возглавляет, организует и направляет деятельность дружин, отрядов, лагерей, - журнал «Вожатый».

Журнал «Вожатый» в этой системе был звеном, связывающим комсомол и пионерскую организацию. Кстати, одним из его основателей был Валериан Зорин, в прошлом лидер скаутов, на советском пространстве - организатор и теоретик пионерского 
движения, затем редактор «Вожатого», впоследствии Чрезвычайный и Полномочный Посол Советского Союза. В далекие 1920-е годы авторы и редакторы закладывали принципы и традиции, которые развивались и обогащались их преемниками и последователями долгие 70 лет. Ао 1990-х годов «Вожатый» соединял в себе различные функции, в том числе:

- информационную, публикуя директивные документы партии, комсомола, самой пионерской организации, ее партнеров - профсоюзов, органов народного образования;

- организаторскую - при непосредственном участии сотрудников редакции разрабатывались, внедрялись в жизнь самые разные начинания и коллективные акции вожатых страны - от конкурсов, игр, смотров до лагерных сборов на базе «Артека», «Орленка», наборов на первые пионерфаки.

Это было уникальное, многофункциональное издание, которое выписывали. Пользовались им не только вожатые, но и комсомольские и пионерские руководители, заместители директоров школ, руководители театральных и хоровых студий. Его можно было найти в столичном Аворце пионеров и в самой дальней сельской школе, в заводском пионерском лагере и в «Артеке», потому что это был необходимый помощник в работе. Из номера в номер семь десятилетий он учил, собирал, наставлял, защищал «комсомольцев-добровольцев», избравших одну из самых необыкновенных, самых благородных творческих профессий - профессию пионерского вожатого.

Исторический опыт взаимодействия Всесоюзной пионерской организации и ее СМИ начиная с 1922 г. и до начала 1990-х годов дает основания сделать вывод, что именно пионерские СМИ становились инициаторами и пропагандистами таких массовых движений, как тимуровское, юнкоровское, красных следопытов, вожатых-производственников и др. (там же: 70-73). Таким образом, можно констатировать, что вновь, уже в советский период в «российской истории ведущей силой выработки новых общественных идей и социальных перемен в обществе была молодежь» (Ильинский, 2017: 21).

\section{СОВРЕМЕННОЕ АОБРОВОАЬЧЕСТВО И ВОАОНТЕРСТВО}

Система способов освоения мира осуществляется через призму ценностей, важных для конкретного человека. Метаценности, высшие, фундаментальные общечеловеческие ценности - это Истина, Аобро, Красота (по советским философским воззрениям) и возвращенные в научный обиход учеными Санкт-Петербурской научной школы теории культуры уже в XXI в. ценности: Вера, Свобода, Аюбовь (Иконникова, Большаков, 2008: 106).

Что же такое ценности? Воспользуемся определением известного российского философа А. В. Гулыги: «Высшие стимулы поведения и есть ценности. Ценностное отношение не совпадает с утилитарным... Утилитарная оценка (суждение типа “Этот предмет мне дорог”) - два различных подхода к действительности, подчас связанных, а порой резко противостоящих друг другу. Нам бывают дороги совершенно бесполезные вещи, наши поступки нередко диктуются не утилитарными соображениями» (Гулыга, 2000: 177). Ценностное отношение всегда эмоционально, человек способен радоваться, получать удовольствие совершенно неутилитарной направленности (Коханая, 2009: 41-42). «Ценность... притягивает нас... мы стремимся к ней, желаем ее. А предмет стремления и есть как раз ценность... все, что человек видит сквозь призму субъективного отношения, неизбежно имеет ценностный характер» (Чавчавадзе, 1979: 69). У каждого человека должны быть ценности, вызывающие у него разнообразный 
спектр чувств: радость, любование, восхищение, благоговение. Это некий каркас, «хребет», на который нанизываются вся информация, все впечатления посредством различных форм освоения действительности личностью. Если вынуть позвоночник из тела, что с ним произойдет?

А у советских, российских граждан четверть века назад - вынули! При советской власти общество развивалось на идеологической основе - человек человеку друг, товарищ и брат. В христианской России существовала идея соборности: возлюби ближнего, как себя самого. В перестройку идеологию осмеяли, в лихие 1990-е - отменили. Подмена появилась незамедлительно. Человек человеку волк. Выживает сильнейший.

Пока мы опомнились, причем на уровне государства, прошло 25 лет. Только в 2015 г. законодатели вспомнили о необходимости духовно-нравственного воспитания подрастающего поколения, и Правительством Российской Федерации была принята Стратегия развития воспитания в Российской Федерации на период до 2025 года, где неотъемлемой частью образования провозглашено воспитание, а условиями воспитания здоровой счастливой личности определены принципы коллективизма, социальной ответственности, милосердия, доброты (Ильинский, Ауков, 2015: Электронный ресурс). Роль государства в восстановлении традиционной системы ценностей и сбережении ментальности социума неоспорима (Коханая, 2016: Электронный ресурс; Смеюха, 2016: 1070). Но пока, в реальности, мы имеем расстрелы и избиения учителей учениками школ и их родителями, подростковые суициды, поножовщину в школах и пр. Причем, как правило, для родителей поступки их детей «за гранью добра и зла»- неожиданность, т. е. Аушевное, доверительное общение, обратная связь и взаимопонимание в семьях отсутствуют. А ведь метаценности семьи - «это те ценности, которые сопутствуют и способствуют стабильности семейных отношений и являются производными от нее, например теплота семейных отношений, взаимное уважение, поддержка » (Реан, 2002: Электронный ресурс).

При очерченных выше проблемах хотелось бы отметить то позитивное, по мнению авторов, что сегодня просматривается в детско-юношеском движении и как отклик в средствах массовой информации.

Первый аспект. «Марш наследников» (кстати, идея придумана журналистом) ныне перерос чуть ли не в национальную идею. Это массовое движение породило искренний интерес у подростков и юношества к истории своей семьи в годы Великой Отечественной войны: они исследуют, ищут старые фотографии, пишут эссе в школах, публикуют статьи в местных газетах; с этой заинтересованностью, приходя в вуз, они публикуют свои материалы в студенческих учебных СМИ: например, в Московском гуманитарном университете (МосГУ) в студенческой газете «Проба пера», литературно-художественном и научно-просветительском альманахе «Зеркало», которые выпускает кафедра журналистики. Студенты университета с интересом занялись работой в архивах района Вешняки города Москвы, изучая биографии и подвиги забытых героев Великой Отечественной войны. Наши студенты подготовили материалы о 50 героях войны, которые опубликованы в МосГУ в форме сборника студенческих работ «Пятьдесят рассказов о войне» (Пятьдесят рассказов, 2017).

Студент-первокурсник кафедры журналистики МосГУ Григорий Егоров, окончивший кадетский корпус (кстати, новое явление постсоветской действительности), по зову сердца выступил 9 мая 2015 г. (70 лет Победы) с благотворительными сольными концертами песен о войне в поселках Подмосковья; с военными песнями перед студентами и абитуриентами в университете. 
Таким образом, можно констатировать некий патриотический всплеск и интерес к национальной истории у подрастающего поколения, т. е. возвращение в самосознание российского человека понятия Родины как непреходящей ценности.

Второй аспект. На новом историческом витке возрождаются различные формы детских общественных организаций и движений, конечно, под руководством взрослых (Алиева, 2002; Трухачева, Кирпичник, 2009). Масса медиаобразовательных проектов (в том числе, региональных), детских СМИ, в том числе самодеятельных, школьные газеты, радио и даже телевидение; масса молодежных и детских региональных и федеральных фестивалей, форумов, конкурсов заполнили культурное пространство России. На добровольных началах как участники и даже организаторы в них участвуют и наши студенты кафедры журналистики МосГУ. Если проанализировать только за 2017 г. дипломы и грамоты наших студентов, то можно говорить о высокой их активности в самодеятельном, в том числе волонтерском, движении.

Например, только Юнпресс организовал Фотокросс, Международный юношеский медиафорум «Артек», детский медиахолдинг «Артек», Всероссийский форум детского экранного творчества «Бумеранг». Наши студенты также участвовали и организовывали Всероссийский образовательный форум «Таврида», Молодежный фестиваль современной фотографии, Международный экологический форум, всероссийские конкурсы - уроки мастерства самоуправления (правительства-дублеры); участвовали в создании новых структур, учредителем которых явилось Министерство образования РФ: Международной ассоциации студенческого телевидения (МАСТ) и прессцентра Московского международного салона образования. Привлекают студентов и молодежные лагеря, форумы молодежного актива (на Селигере, Клязьме).

Увлекает как школьников, так и студентов волонтерство. Например, уже три года в оздоровительном комплексе «Снегири» Управления делами Президента РФ круглый год проходит акция «Аети России - детям Аонбасса», где наши студенты работают в качестве вожатых и воспитателей. эгидой Студенческого совета МосГУ наши студенты осуществляют добровольное шефство над детскими домами, интернатами. Кроме того, что это расширение кругозора молодежи, это и «прикипание» души к своей Родине. Обычный активный первокурсник из глубинки Никита Юртаев (Ямало-Ненецкий округ) уже в ноябре 2017 г. был приглашен как активист на встречу волонтеров с Президентом РФ В. В. Путиным.

Что вызывает тревогу?

Ааже в этих позитивных проявлениях социальной деятельности гносеологической и аксиологической направленности каждый из студентов ведет себя как бы вне коллектива: непосредственное общение зачастую их пугает, чувство коллективизма практически отсутствует. Студенты-журналисты с трудом находят себе даже одного друга-приятеля в студенческой группе. «Больше двух» и не собираются. Все эти бесконечные, часто бесплатные тренинги личностного роста в различных организациях, зазывания которых легко найти по Интернету, воспитали индивидуалистов, циников, приспособленцев (если есть предполагаемая личная выгода) и уж точно не героев!

А ведь высшие ценности - Истина, Аобро, Красота, Вера, Свобода, Аюбовь - актуальны лишь тогда, когда есть с кем разделить ощущения, когда этими ценностями или лично тобой кто-то восхитится. Исчезло у молодых чувство коллективизма, выражаясь по-советски, или ощущение соборности, как то было в дореволюционной России. Но это ведь наш менталитет, наш национальный код: пока мы едины, мы непобедимы! 
Этими размышлениями один из соавторов статьи поделилась не только с преподавателями журналистских дисциплин на конференции «Журналистика в 2017 году: творчество, профессия, индустрия» в МГУ им. М. В. Аомоносова (Коханая, 2018), что вызвало дискуссии и некоторые сомнения у преподавателей разных поколений, но и со студентами-журналистами первого и второго курсов Московского гуманитарного университета. Студенты полностью согласились с нашими где-то жесткими оценками молодого поколения.

\section{ЗАКАЮЧЕНИЕ}

Подводя итоги, отметим, что с начала XX в. детско-юношеские общественные движения и отечественная детская периодика являлись важными факторами ценностного самоопределения личности детей и юношества. С одной стороны, можно проследить преемственность традиций и принципов патриотического, нравственного воспитания, уважения к личности ребенка в досоветский и советский период развития нашей страны. С другой стороны, воздействие системы отечественных СМИ для детей в СССР беспрецедентно по масштабу целей и задач, по массовому охвату и вовлечению молодого поколения в добровольные общественные движения и в осуществление пионерами и комсомольцами различных инициатив вдохновенного, бескорыстного и самоотверженного служения Родине. Конечно, были и недостатки, что естественно, но очевидны такие достижения советских детей, которые и не снились, да и неизвестны современному молодому поколению. И все-таки новые формы организации детей и молодежи нарождаются и должны способствовать пробуждению самосознания народа, созиданию будущего России.

\section{ПРИМЕЧАНИЕ}

1 Все это достаточно полно уже было систематизировано и отражено авторами в учебном пособии «Отечественные средства массовой информации для детей», кстати, и по сей день единственном в России по данной тематике (Головин, Зарахович, Коханая, 2011).

\section{СПИСОК АИТЕРАТУРЫ}

Алиева, А. В. (2002) Аетское движение - субъект воспитания: теория, история, практика. M. : MAKС Пресс. 322 c.

Баден-Пауэлл, Р. (2001) Настольная книга скаута : пер. с англ. / М. : Русская книга. Библиотека Всемирной Кругосветной экспедиции ЮНЕСКО. 368 с.

Бондарь, А. А. (1993) Скаутинг. Книга для скаута. Женева, Швейцария : Всемирная организация скаутского движения. 175 с.

Бондарь, А. А. (1992) Что есть скаутинг. Книга для скаутского лидера. Женева, Швейцария : Всемирная организация скаутского движения. 64 с.

Головин, Ю. А., Зарахович, И. С., Коханая, О. Е. (2011) Отечественные средства массовой информации для детей : учеб. пособие. Кн. 1. М. : МГУКИ. 170 с.

Головин, Ю. А. (2010) Российские литературно-художественные журналы в системе культурной политики: содействие, компромисс, противостояние : дис. ... А-ра культурологии. M. 327 c.

Горький, М. (1953) О литературе : литературно-критические статьи. М. : Советский писатель. 214 с.

Гулыга А. В. (2000) Эстетика в свете аксиологии. Пятьдесят лет на Волхонке. СПб. : Алетейя. 445 с.

Ермолин, А. А. (2004) Навигатор третьего тысячелетия, или Как стать разведчиком. М. : Народное образование. $425 \mathrm{c}$. 
Иконникова, С. Н., Большаков, В. П. (2008) Теория культуры. СПб. : Питер. 592 с.

Ильинский, И. М. (2017) Молодежь и революция (әскиз к политическому портрету) // Знание. Понимание. Умение. № 2. С. 6-28.

Ильинский, И. М., Ауков, В. А. (2015) О стратегии развития воспитания в Российской Федерации на период до 2025 года [Электронный ресурс]// Научные труды Московского гуманитарного университета. №1. URL: http://journals.mosgu.ru/trudy/article/view/6 (дата обращения: 06.03.2018). DOI: 10.17805/trudy.2015.1.6

Кордонский, М., Кожаринов, М. (2008) Очерки неформальной социотехники. M. : Net2Net. $336 \mathrm{c}$

Коханая, О. Е. (2018) Многообразие средств массовой информации в начале XX в. в России // Журналистика в 2017 году: творчество, профессия, индустрия. Сборник материалов международной научно-практической конференции / отв. ред. Е. А. Вартанова, Я. Н. Засурский. М. : МедиаМир ; Факультет журналистики МГУ имени М. В. Аомоносова. 616 с. С. 519-520.

Коханая, О. Е. (2016) Формы коммуникативного сотрудничества в вузе в условиях информационно-технологических перемен [Электронный ресурс]// Научные труды Московского гуманитарного университета. № 3 URL: http://journals.mosgu.ru/trudy/article/view/290 (дата обращения: 13.03.18). DOI: 10.17805/trudy.2016.3.3

Коханая, О. Е. (2009) Социокультурные функции детского театра : дис. ... А-ра культурологии. М. 296 с.

Кучин, В. А. (2008) Скауты России. 1909-2007. История. Аокументы. Свидетельства. Воспоминания. М. : Минувшее. 600 с.

Пионерская правда (1946) 19 апреля.

Пионерская правда (1937) 24 января.

Пионерия Москвы: вехи истории (2018) // Про_АОА: информационно-методический журнал. № 2 (14), апрель. URL: http://prodod.moscow/archives/1660 (дата обращения: 13.05.18).

Попов, В. А., Преображенский, В. С. (1917) Бой-скауты : руководство самовоспитания молодежи по системе «скаутинг» сэра Роберта Баден-Поуэлля применительно к условиям русской жизни и природы. М. : Тип. Сытина. 383 с.

Пятьдесят рассказов о войне (2017) / редкол.: Е. А. Белый, С. В. Алексеев, О. Г. Жуков, А. А. Инков. М. : Изд-во Моск. гуманит. ун-та. 68 с.

Реан, А. А. (2002) Психология человека от рождения до смерти. СПб. : ПРАЙМ-ЕВРО3HAK. 656 c.

Северное сияние : ежемесячный журнал для детей (9-12 лет) (1919). № 1. СПб. 63 с.

Смеюха, В. В. (2016) Конкурсы юных журналистов: функциональные и типологические характеристики // Ученые записки Казанского университета. Т. 158. Кн. 4. 1218 с. С. 1064-1076.

Трухачева, Т. В., Кирпичник, А. Г. (2009) Основы социокинетики детства. М. : Ассоциация исследователей детского движения. 528 с.

Чавчавадзе, Н. 3. (1979) Культура и ценности // Культура в свете философии / под ред. Н. 3. Чавчавадзе. Тбилиси : Хеловнеба. 324 с. С. 31-72.

Аата поступления: 14.05 .2018 2.

\section{CHILDREN'S AND YOUTH SOCIAL MOVEMENTS AND DOMESTIC CHILDREN'S PERIODICALS AS FACTORS OF VALUE PERSONAL IDENTITY \\ Yu. A. Golovin, O. E. KoKHANAYA \\ MOSCOW UNIVERSITY FOR THE HUMANITIES}

The authors examine the history of the development of the children's and youth movement in Russia in connection with the development of the domestic children's periodicals, which were an upbringing factor, forming the values of the movement's participants.

The prototype of the first children's and youth organisations was the scout movement, which appeared in the UK in the early twentieth century. R. Baden-Powell's ideas found followers in Russia. 
The main distinguishing feature of the Russian scouting was the military and patriotic orientation. Analysing the situation of the rapid spread of the Scout movement in Russia, the authors come to the conclusion that this was made possible by the creation of an effective model of functioning of scouting media. Based on a study of prerevolutionary domestic media for children and young people, the authors argue that the pioneer media that were created in the early years of the Soviet period were organised and functioned in the same mode, only with a different ideological content. In the meantime, the patriotic education of the young generation remained the dominant vector in the new political system of coordinates.

The next stage was the activities of the media during the «pre-pioneer period», the functioning of the Pioneer Organisation in the life of children in the USSR (the 1920s-1980s). The stage is characterised by joint activities with Komsomol organisations on combating homelessness, eliminating illiteracy in the 1920s-1930s, the preparation of youth for service in the Soviet army, etc. New forms of organising children and youth (volunteering and voluntarism) have got their media as well.

The continuity of traditions and principles of patriotic and moral education, respect for the child's personality in the pre-Soviet and Soviet period of the development of our country is evident. The impact that the system of domestic media had on children in the USSR is unprecedented in terms of the scale of goals and objectives, the mass coverage and involvement of the younger generation in voluntary social movements.

Keywords: patriotic educacion; value personal identification; children's and youth public organisations; scouting; Pioneer Organisation; mass media; periodical press; volunteering; volunteerism; history of Russia; history of the USSR

\section{REFERENCES}

Alieva, L. V. (2002) Detskoye dvizheniye - sub»yekt vospitaniya: teoriya, istoriya, praktika. Moscow, MAX Press. 322 p. (In Russ.).

Baden-Powell, R. (2001) Nastol'naya kniga skauta. Moscow, The Russian Book, Library of the World Circumnavigation Expedition of UNESCO. 368 p. (In Russ.).

Bondar, L. A. (1993) Skauting. Kniga dlya skauta. Geneva, Switzerland, World Organization of the Scout Movement.175 p. (In Russ.).

Bondar, L. A. (1992) Chto yest' skauting. Kniga dlya skautskogo lidera. Geneva, Switzerland, World Organization of the Scout Movement. 64 p. (In Russ.).

Golovin, Yu. A., Zarahovich, I. S. and Kokhanaya O. E. (2011) Otechestvennyye sredstva massovoy informatsii dlya detey. Textbook. The UFO facial. Book 1. Moscow, MGUKI. 170 p. (In Russ.).

Golovin, Yu. A. (2010) Rossiyskiye literaturno-kbudozhestvennyye zhurnaly v sisteme kul' turnoy politiki: sodeystviye, kompromiss, protivostoyaniye: Dis. ... Doctor of Culturology. Moscow. 327 p. (In Russ.). Russ.).

Gorky M. (1953) O literature: Literaturno-kriticheskiye stat' $i$. Moscow, Soviet writer. 214 p. (In

Gulyaga A. V. (2000) Estetika v svete aksiologii. Pyat'desyat let na Volkbonke. St. Petersburg, Aletheia. 445 p. (In Russ.).

Ermolin, A. A. (2004) Navigator tret'yego tysyacheletiya, ili Kak stat' razvedchikom. Moscow, Public education. 425 p. (In Russ.). Russ.).

Ikonnikova, S. N., Bolshakov, V. P. (2008) Teoriya kul'tury. St. Petersburg, Peter. 592 p. (In

Ilyinsky, I. M. (2017) Molodezh' i revolyutsiya (eskiz k politicheskomu portretu). Znaniye. Ponimaniye. Umeniye, no. 2, pp. 6-28. (In Russ.).

Ilyinsky, I. M. and Lukov, V. A. (2015) O strategii razvitiya vospi-taniya v Rossiyskoy Federatsii na period do 2025 goda. Nauchnyye trudy Moskovskogo gumanitarnogo universiteta, no. 1 (169) [online] Available at: http://journals.mosgu.ru/trudy/article/view/6 (access date: 06.03.2018). DOI: 10.17805/trudy.2015.1.6 (In Russ.).

Kordonsky, M. and Kozharinov, M. (2008) Ocherki neformal'noy sotsiotekbniki. Moscow, Net2Net Publ. 336 p. (In Russ.). 
Kokhanaya, O. E. (2018) Mnogoobraziye sredstv massovoy informatsii v nachale XX v. v Rossii. Zhurnalistika $v 2017$ godu: tvorchestvo, professiya, industriya. Collection of materials of the international scientific-practical conference / Ed. by E. L. Vartanova and Ya. N. Zasursky. Moscow, MediaMir, Faculty of Journalism of Lomonosov Moscow State University. 616 p. Pp. 519-520. (In Russ.).

Kokhanaya, O. E. (2016) Formy kommunikativnogo sotrudnichestva v vuze v usloviyakh informatsionno-tekhnologicheskikh peremen. Nauchnyye trudy Moskovskogo gumanitarnogo universiteta, no. 3 [online] Available at: http://journals.mosgu.ru/trudy/article/view/290 (access date: 13.03.2018). DOI: 10.17805/trudy.2016.3.3 (In Russ.).

Kokhanaya, O. E. (2009) Sotsiokul' turnyye funktsii detskogo teatra: Diss. ... Doctor of Culturology. Moscow. 296 p. (In Russ.).

Kuchin, V. L. Skauty Rossii. 1909-2007. Istoriya. Dokumenty. Svidetel'stva. Vospominaniya. Moscow, Past. 600 p. (In Russ.).

Pionerskaya pravda (1946) April 19. (In Russ.).

Pionerskaya pravda (1937) January 24. (In Russ.).

Pioneriya Moskvy: vekhi istorii (2018). Pro_DOD: informatsionno-metodicheskiy zhurnal. № 2 (14). April [online] Available at: http://prodod.moscow/archives/1660 (access date: 13.05.18). (In Russ.).

Popov, V. A. and Preobrazhensky, V. S. (1917) Boy-skauty : rukovodstvo samovospitaniya molodezhi po sisteme "skauting» sera Roberta Baden-Pouellya primenitel' no k usloviyam russkoy zhizni i prirody. Moscow, Type. Sytin. V. 1-12. 383 p. (In Russ.).

Pyat'desyat rasskazov o voyne (2017) rare: E. A. White, S. V. Alekseev, O. G. Zhukov and A. A. Incov. Moscow, Publishing house of the Moscow Humanitarian University. 68 p. (In Russ.).

Rean, A. A. (2002) Psikbologiya cheloveka ot rozhdeniya do smerti. St. Petersburg, PRIMEEVROZNAK. 656 p.

Severnoye siyaniye: yezhemesyachnyy zhurnal dlya detey (9-12 let), no. 1. St. Petersburg. 63 p. (In Russ.).

Smeyukha, V. V. (2016) Konkursy yunykh zhurnalistov: funktsional'nyye i tipologicheskiye kharakteristiki. Uchenyye zapiski Kazanskogo universiteta, vol. 158, book. 4, pp. 1064-1076. (In Russ.).

Trukhacheva, T. V. and Kirpichnik, A. G. (2009) Osnovy sotsiokinetiki detstva. Moscow, Association of Researchers of the Children's Movement. 528 p. (In Russ.).

Chavchavadze, N. Z. (1979) Kul'tura i tsennosti. Kul'tura v svete filosofii / Ed. by N. S. Chavchavadze. Tbilisi, Helovneba. 324 p. Pp. 31-72. (In Russ.).

Submission date: 14.05 .2018$.

Головин Юрий Алексеевич - доктор культурологии, доцент, заведующий кафедрой журналистики Московского гуманитарного университета. Адрес: 111395, Россия, г. Москва, ул. Юности, д. 5. Тел.: +7 (499) 374-60-91. Эл. адрес: ygolovin@mosgu.ru

Коханая Ольга Евгеньевна - доктор культурологии, доцент, профессор кафедры журналистики Московского гуманитарного университета. Адрес: 111395, Россия, г. Москва, ул. Юности, д. 5. Тел.: +7 (495) 374-60-91. Эл. адрес: kokhanaya@mail.ru

Golovin Yuriy Alekseyevich, Doctor of Culturology, Head, Department of Journalism, Moscow University for the Humanities. Postal address: 5, Yunosti St., Moscow, Russian Federation, 111395. Tel.: +7 (499) 374-60-91. E-mail: ygolovin@mosgu.ru

Kokhanaya Olga Evgenyevna, Doctor of Culturology, Associate Professor, Professor, Department of Journalism, Moscow University for the Humanities. Postal address: 5, Yunosti St., Moscow, Russian Federation, 111395. Тел.: +7 (495) 374-60-91. Эл. aspec: kokhanaya@mail.ru 